\title{
Prevalence and genotypic identification of Cryptosporidium in free-ranging and farm-raised donkeys (Equus asinus asinus) in Xinjiang, China
}

\author{
Wen Wang ${ }^{1}$, Zhenjie Zhang ${ }^{2}$, Ying Zhang ${ }^{1}$, Aiyun Zhao ${ }^{1}$, Bo Jing ${ }^{1}$, Longxian Zhang ${ }^{2}$, Pengtao Liu ${ }^{3}$, Meng Qi ${ }^{1, *}$, \\ and Wei Zhao ${ }^{4}$ \\ ${ }^{1}$ College of Animal Science, Tarim University, Alar, Xinjiang 843300, P.R. China \\ 2 College of Animal Science and Veterinary Medicine, Henan Agricultural University, Zhengzhou, Henan 450002, P. R. China \\ ${ }^{3}$ College of Life Sciences, Tarim University, Alar, Xinjiang 843300, P.R. China \\ ${ }^{4}$ Department of Parasitology, Wenzhou Medical University, Wenzhou, Zhejiang Province 325035, P.R. China
}

Received 5 December 2019, Accepted 16 June 2020, Published online 25 June 2020

\begin{abstract}
The prevalence and zoonotic potential of Cryptosporidium in donkeys is poorly understood. Here, 680 fecal specimens were collected from 178 free-ranging and 502 farmed donkeys in Xinjiang, China. Cryptosporidium was identified using PCR amplification of the small subunit of ribosomal DNA. Cryptosporidium-positive isolates were subtyped using PCR analysis of the $60 \mathrm{kDa}$ glycoprotein gene (gp60). The overall prevalence of Cryptosporidium was $2.4 \%(16 / 680)$, with $3.2 \%(16 / 502)$ in farmed donkeys and $0 \%(0 / 178)$ in free-ranging donkeys. Cryptosporidium hominis $(n=13), C$. parvum $(n=1)$ and Cryptosporidium horse genotype $(n=2)$ were identified. The $C$. hominis isolates belonged to two subtypes, IkA16 $(n=9)$ and IkA16G1 $(n=4)$. The subtype of $C$. parvum was IIdA15G1, whereas the two Cryptosporidium horse genotype isolates were of subtype VIaA15G4. The predominance of C. hominis in donkeys suggests that these animals are infected through human contact.
\end{abstract}

Key words: Cryptosporidium, Donkey, Genotyping, Zoonotic potential.

\begin{abstract}
Résumé - Prévalence et identification génotypique des Cryptosporidium chez les ânes (Equus asinus asinus) en liberté et en élevage au Xinjiang, Chine. La prévalence et le potentiel zoonotique de Cryptosporidium chez les ânes sont mal connus. Dans cet article, 680 spécimens fécaux ont été prélevés de 178 ânes en liberté et 502 ânes en élevage dans le Xinjiang, en Chine. Les Cryptosporidium ont été identifiés en utilisant une amplification par PCR de la petite sous-unité de l'ADN ribosomique. Les isolats positifs pour Cryptosporidium ont été sous-typés en utilisant une analyse PCR du gène de la glycoprotéine $60 \mathrm{kDa}$ (gp60). La prévalence globale de Cryptosporidium était de 2,4 \% (16/680), avec 3,2\% (16/502) chez les ânes d'élevage et $0 \%(0 / 178)$ chez les ânes en liberté. Cryptosporidium hominis $(n=13)$, C. parvum $(n=1)$ et Cryptosporidium génotype chevalin $(n=2)$ ont été identifiés. Les isolats de $C$. hominis appartenaient à deux sous-types, IkA16 $(n=9)$ et IkA16G1 $(n=4)$. Le sous-type de $C$. parvum était IIdA15G1, tandis que les deux isolats de Cryptosporidium génotype chevalin étaient du sous-type VIaA15G4. La prédominance de $C$. hominis chez les ânes suggère que ces animaux sont infectés par contact humain.
\end{abstract}

\section{Introduction}

Cryptosporidium is an important zoonotic parasitic pathogen that causes diarrhea in humans and various animal species [19]. To date, at least 39 species and more than 70 genotypes of Cryptosporidium have been described [8, 13]. Among them, $C$. hominis and $C$. parvum are the most common species identified in humans $[6,15]$. Previous studies indicate that

\footnotetext{
*Corresponding author: qimengdz@163.com
}

C. hominis and C. parvum are the dominant species that infect horses and donkeys [8, 14].

The zoonotic nature of various Cryptosporidium species implies that public health may be affected by infected animals [19]. Contact with farmed animals has been identified as a risk factor for disease in case-control studies of sporadic human cryptosporidiosis [7]. Additionally, several outbreaks involving veterinary and farm school students have been documented, including children and students infected with C. parvum after visiting open farms and outdoor adventure farms in England $[5,12]$. Moreover, an Italian study reported a foal at a 
racecourse with severe diarrhea caused by $C$. parvum infection, and the subsequent infection of six students with the same subtype of $C$. parvum after visiting the racecourse, resulting in diarrhea or abdominal pain [11].

The donkey has been used as a working animal for at least 5000 years. China has the largest number of donkeys, at 11 million, and they are used principally as pack animals or for draught work in transport or agriculture. Some donkeys are raised for milk or meat, as well as for making Ejiao, a traditional Chinese medicine product. To our knowledge, only two reports have been published about Cryptosporidium infection of donkeys in China [14, 17]. The present study aimed to determine the prevalence and zoonotic potential of Cryptosporidium in free-ranging and scale-farmed donkeys in Xinjiang, China.

\section{Materials and methods \\ Ethics statement}

The research protocol was reviewed and approved by the Research Ethics Committee of Tarim University. Before collecting fecal specimens, we contacted the managers of donkey farms or donkey owners, and obtained their permission to have their animals involved. No animals were injured during this procedure.

\section{Collection of fecal specimens}

From May 2016 to December 2018, 680 fresh fecal specimens (approximately $50 \mathrm{~g}$ per specimen) were collected from 178 free-ranging donkeys at five locations and 502 farmed donkeys from 18 farms in 12 cities of Xinjiang, China (Table 1). All fecal specimens were collected from the ground immediately after defecation using a sterile disposable latex glove. The number of collected specimens accounted for $10 \%-30 \%$ of the adult or young donkeys at each farm and all free-ranging donkeys in the countryside. All specimens were transported to the laboratory in a cooler with ice packs, and stored at $4{ }^{\circ} \mathrm{C}$ until processing. The ages of the adult and young donkeys were $\geq 1$ year and $<1$ year old, respectively. None of the animals showed any clinical symptoms at the time of sampling.

\section{DNA extraction}

All the fecal specimens were sieved through an 8.0-cmdiameter sieve with a pore size of $45 \mu \mathrm{m}$, and the filtrates were concentrated by centrifugation at $1500 \times g$ for $10 \mathrm{~min}$, then genomic DNA was extracted from approximately $200 \mathrm{mg}$ of precipitates using an E.Z.N.A. stool DNA kit (Omega Biotek Inc., Norcross, GA, USA), according to the manufacturer's instructions. A total of $200 \mu \mathrm{L}$ of extracted DNA from each specimen was transferred to Eppendorf tubes and stored at $-20{ }^{\circ} \mathrm{C}$ until PCR amplification.

\section{Genotyping and subtyping of Cryptosporidium}

Cryptosporidium spp. were identified using nested PCR amplification of a partial small subunit of ribosomal DNA
(SSU rDNA) gene fragment of $\sim 830$ bp using primers previously described by Xiao et al. [21]. All Cryptosporidiumpositive isolates were further subtyped using nested PCR amplification of an $\sim 850 \mathrm{bp}$ fragment of the gene encoding a $60-\mathrm{kDa}$ glycoprotein ( $g p 60$ ) using primers previously described by Alves et al. [2]. All PCR amplifications included positive controls (chicken-derived $C$. bailey DNA) and negative controls $\left(\mathrm{dH}_{2} \mathrm{O}\right)$.

\section{DNA sequencing and analysis}

All nested PCR-positive products were sent for sequencing by GENEWIZ (Suzhou, China). The accuracy of the sequencing data was confirmed by sequencing the PCR products using both the forward and the reverse primer. Species and genotypes of Cryptosporidium were identified by comparing nucleotide sequences with each other and with published GenBank sequences using the Basic Local Alignment Search Tool (BLAST) (http://blast.ncbi.nlm.nih.gov/Blast.cgi) and ClustalX2.11 (http://www.clustal.org/).

\section{Statistical analysis}

Data entry and analysis were performed using SPSS 19.0 software (IBM Corp., Armonk, NY, USA). Prevalence was calculated according to feeding pattern and age (young $v s$. adult donkey). Categorical variables were expressed as numbers of cases (percentages) and frequencies were compared using chi square tests with $p<0.05$ considered statistically significant.

\section{Nucleotide sequence accession numbers}

Representative sequences of Cryptosporidium were deposited in GenBank under accession numbers MK731970 to MK731972 (SSU rRNA) and MK731973 to MK731976 (gp60).

\section{Results and discussion}

Sixteen fecal specimens were positive for Cryptosporidium from six farms in four cities with an overall infection rate of $2.4 \%(16 / 680)$, which is similar to that previously reported for donkeys in Algeria $(1.6 \%, 2 / 124)$ [16]. The infection rate of Cryptosporidium in farmed donkeys was $3.2 \%$ (16/502), whereas none of the free-ranging donkeys harbored Cryptosporidium infection (Table 1). The infection rate of Cryptosporidium in young donkeys $(4.4 \%, 13 / 296)$ was higher than that in adults $(0.9 \%, 3 / 323)$, and this difference was statistically significant $\left(\chi^{2}=7.36, p<0.01\right)$. In fact, it is not only in donkeys that young animals are more likely to carry Cryptosporidium infections, this is true for most host species. There are a great many studies, especially in cattle, which clearly indicate a much higher prevalence of Cryptosporidium in young animals $[1,4]$. These data suggest that age may be a risk factor for Cryptosporidium infection in animals including donkeys. Moreover, Cryptosporidium infections can be transmitted amongst animals on farms because of group feeding habits and shared feeding environments. The present study did not in- 
Table 1. Prevalence, species/genotypes and subtypes of Cryptosporidium in donkeys in Xinjiang, China.

\begin{tabular}{|c|c|c|c|c|}
\hline $\begin{array}{l}\text { Feeding } \\
\text { pattern }\end{array}$ & Collection site & Age (year) & $\begin{array}{c}\text { No. positive/ } \\
\text { No. samples }(\%)\end{array}$ & Cryptosporidium species, subtype $(n)$ \\
\hline \multicolumn{5}{|l|}{ Farmed } \\
\hline & Alaer (Farm 1) & $<1$ & $0 / 54$ & 1 \\
\hline & Barkol (Farm 2) & $<1$ & 2/11 (18.2) & C. horse genotype (2), VIaA15G4 (2) \\
\hline & Bohu (Farm 3) & $\geq 1$ & $0 / 27$ & / \\
\hline & Bohu (Farm 4) & $\geq 1$ & $2 / 34(5.9)$ & C. hominis (2), IkA16 (2) \\
\hline & Bohu (Farm 5) & $<1$ & $1 / 18(5.6)$ & C. hominis (1), IkA16 (1) \\
\hline & Gongliu (Farm 6) & $<1$ & $0 / 21$ & I \\
\hline & Huocheng (Farm 7) & $<1$ & $0 / 20$ & 1 \\
\hline & Karakax (Farm 8) & $<1$ & $5 / 41(12.2)$ & C. hominis (5), IkA16 (3), IkA16G1 (2) \\
\hline & Karakax (Farm 9) & $<1$ & $0 / 47$ & 1 \\
\hline & Khorgas (Farm 10) & Unclear & $0 / 20$ & I \\
\hline & Pishan (Farm 11) & Unclear & $0 / 26$ & l \\
\hline & Pishan (Farm 12) & Unclear & $0 / 15$ & / \\
\hline & Qitai (Farm 13) & $\geq 1$ & $0 / 16$ & l \\
\hline & Turpan (Farm 14) & $<1$ & $0 / 17$ & l \\
\hline & Yopurga (Farm 15) & $<1$ & $3 / 12(25.0)$ & C. hominis (3), IkA16 (3) \\
\hline & & $\geq 1$ & $1 / 24(4.2)$ & C. parvum (1), IIdA15G1 (1) \\
\hline & Yopurga (Farm 16) & $<1$ & $0 / 10$ & 1 \\
\hline & & $\geq 1$ & $0 / 44$ & 1 \\
\hline & Yopurga (Farm 17) & $<1$ & $2 / 13(15.4)$ & C. hominis (2), IkA16G1 (2) \\
\hline & Yuli (Farm 18) & $<1$ & $0 / 32$ & 1 \\
\hline & Subtotal & & $16 / 502(3.4)$ & $\begin{array}{l}\text { C. hominis (13), IkA16 (9), IkA16G1 (4); } \\
\text { C. parvum (1), IIdA15G1 (1); Cryptosporidium } \\
\text { horse genotype, VIaA15G4 (2) }\end{array}$ \\
\hline \multicolumn{5}{|l|}{ Free-ranging } \\
\hline & Akqi (Location 1) & $\geq 1$ & $0 / 11$ & / \\
\hline & Barkol (Location 2) & $\geq 1$ & $0 / 21$ & / \\
\hline & Pishan (Location 3) & $\geq 1$ & $0 / 48$ & l \\
\hline & Yecheng (Location 4) & $\geq 1$ & $0 / 64$ & l \\
\hline & Zepu (Location 5) & $\geq 1$ & $0 / 34$ & l \\
\hline & Subtotal & & $0 / 178$ & 1 \\
\hline \multirow[t]{2}{*}{ Total } & & $<1$ & $13 / 296(4.4)$ & $\begin{array}{l}\text { C. hominis (11), IkA16 (7), IkA16G1 (4); } \\
\text { Cryptosporidium horse genotype (2), VIaA15G4 (2) }\end{array}$ \\
\hline & & $\begin{array}{c}\geq 1 \\
\text { Unclear }\end{array}$ & $\begin{array}{c}3 / 323(0.9) \\
0 / 61\end{array}$ & C. hominis (2), IkA16 (2); C. parvum (1), IIdA15G1 (1) \\
\hline
\end{tabular}

clude any young free-ranging donkeys, only young farmed donkeys, which might have skewed the infection rate findings.

To date, three Cryptosporidium species (C. parvum, $C$. muris, and $C$. hominis) and only one genotype (Cryptosporidium horse genotype) have been identified in donkeys $[14,16,17]$. In the present study, 16 Cryptosporidium-positive specimens underwent successful sequencing of the SSU rDNA gene. Three species/genotype were identified, including C. hominis $(n=13)$, C. parvum $(n=1)$, and the Cryptosporidium horse genotype $(n=2)$ (Table 1$)$.

Cryptosporidium hominis had the highest frequency $(81.3 \%, 13 / 16)$ in this study, and was detected on six Cryptosporidium-positive farms from four areas (Table 1). C. hominis is widely considered a human-specific Cryptosporidium species, but also commonly infects nonhuman primates, horses, and donkeys, which appear to be typical hosts $[8,14,16]$. Most $C$. hominis isolates from horses and donkeys have been identified as divergent subtypes of the host-adapted Ik subtype family, including IkA15G1, IkA20G1, IkA16, and IkA16G1 [14]. In the present study, two subtypes were identified, IkA16 $(n=9)$ and IkA16G1 $(n=4)$, with IkA16 as the dominant subtype (Table 1). To date, these have only been identified in horses and donkeys, indicating that they are host-adapted $C$. hominis subtypes with limited public health significance.

Cryptosporidium parvum has been detected in donkeys from Algeria and China $[14,16]$. In the present study, C. parvum was detected in an adult farmed donkey, as subtype IIdA15G1 (Table 1), which differs from the previously reported C. parvum subtype IIdA19G1 in donkeys from Shandong and Henan, China [14]. The IIdA15G1 subtype has been identified in humans and a variety of animals, being particularly common in cattle and various rodents in China [9]. The IIdA15G1 subtype of $C$. parvum in a donkey was likely to have been transmitted from humans or other animals, particularly cattle and rodents, but the real source of infection and transmission require further analysis.

The Cryptosporidium horse genotype has been identified in donkeys in China [14]. In the present study, the Cryptosporidium horse genotype was detected in two young farmed donkeys with the same subtype, VIaA15G4 (Table 1). This subtype has been detected in China, Italy, and the Czech Republic [3, 10, 14, 18, 20]. Currently, only two subtype families have been identified in the Cryptosporidium horse genotype: VIa in 
animals and VIb in humans and hedgehogs [14]. The host specificity of the VIa and VIb subtype families is not completely understood because of limited data, so further investigation is needed to elucidate the source of the Cryptosporidium horse genotype infection and the cross-species transmission potential of this genotype in donkeys, other animals, and humans in China.

\section{Conclusions}

This study demonstrated the occurrence of Cryptosporidium infection in donkeys in Xinjiang, China. Three species or genotype of Cryptosporidium were identified, including C. parvum, C. hominis, and the Cryptosporidium horse genotype; all of these have previously been detected in humans. Future epidemiologic studies of Cryptosporidium should preferentially focus on donkeys to understand the true epidemiology of Cryptosporidium and its transmission dynamics in China.

\section{Conflict of interest}

The authors declare that they have no conflict of interest.

Acknowledgements. This study was partly supported by the National Natural Science Foundation of China (31660712 and 31702227), the Program for Young and Middle-aged Leading Science, Technology, and Innovation of Xinjiang Production \& Construction Group (2018CB034), and the President Foundation of Tarim University (TDZKCX201701).

\section{References}

1. Abdullah DA, Ola-Fadunsin SD, Ruviniyia K, Gimba FI, Chandrawathani P, Lim YAL, Jesse FFA, Sharma RSK. 2019. Molecular detection and epidemiological risk factors associated with Cryptosporidium infection among cattle in Peninsular Malaysia. Food Waterborne Parasitology, 14, e00035.

2. Alves M, Xiao L, Sulaiman I, Lal AA, Matos O, Antunes F. 2003. Subgenotype analysis of Cryptosporidium isolates from humans, cattle, and zoo ruminants in Portugal. Journal of Clinical Microbiology, 1, 2744-2747.

3. Caffara M, Piva S, Pallaver F, Iacono E, Galuppi R. 2013. Molecular characterization of Cryptosporidium spp. from foals in Italy. Veterinary Journal, 198, 531-533.

4. Cai Y, Zhang NZ, Gong QL, Zhao Q, Zhang XX. 2019. Prevalence of Cryptosporidium in dairy cattle in China during 2008-2018: A systematic review and meta-analysis. Microbial Pathogenesis, 132, 193-200.

5. Chalmers RM, Smith R, Elwin K, Clifton-Hadley FA, Giles M. 2011. Epidemiology of anthroponotic and zoonotic human cryptosporidiosis in England and Wales, 2004-2006. Epidemiology and Infection, 139, 700-712.

6. Checkley W, White AC Jr, Jaganath D, Arrowood MJ, Chalmers RM, Chen XM, Fayer R, Griffiths JK, Guerrant RL, Hedstrom L, Huston CD, Kotloff KL, Kang G, Mead JR, Miller M, Petri WA Jr, Priest JW, Roos DS, Striepen B, Thompson
RC, Ward HD, Van Voorhis WA, Xiao L, Zhu G, Houpt ER. 2015. A review of the global burden, novel diagnostics, therapeutics, and vaccine targets for Cryptosporidium. Lancet Infection Disease, 15(1), 85-94.

7. Conrad CC, Stanford K, Narvaez-Bravo C, Callaway T, McAllister T. 2017. Farm fairs and petting zoos: a review of animal contact as a source of zoonotic enteric disease. FoodBorne Pathogens and Disease, 14, 59-73.

8. Feng Y, Ryan UM, Xiao L. 2018. Genetic diversity and population structure of Cryptosporidium. Trends in Parasitology, 34(11), 997-1011.

9. Feng Y, Xiao L. 2017. Molecular epidemiology of cryptosporidiosis in China. Frontiers in Microbiology, 8, 1701.

10. Galuppi R, Piva S, Castagnetti C, Iacono E, Tanel S, Pallaver F, Fioravanti ML, Zanoni RG, Tampieri MP, Caffara M. 2015. Epidemiological survey on Cryptosporidium in an equine perinatology unit. Veterinary Parasitology, 210, 10-18.

11. Galuppi R, Piva S, Castagnetti C, Sarli G, Iacono E, Fioravanti ML, Caffara M. 2016. Cryptosporidium parvum: From foal to veterinary students. Veterinary Parasitology, 219, 53-56.

12. Hoek MR, Oliver I, Barlow M, Heard L, Chalmers R, Paynter S. 2008. Outbreak of Cryptosporidium parvum among children after a school excursion to an adventure farm, south west England. Journal of Water and Health, 6, 333-338.

13. Holubová N, Zikmundová V, Limpouchová Z, Sak B, Konečný R, Hlásková L, Rajský D, Kopacz Z, McEvoy J, Kváč M. 2019. Cryptosporidium proventriculi sp. n. (Apicomplexa: Cryptosporidiidae) in Psittaciformes birds. European Journal of Protistology, 69, 70-87.

14. Jian F, Liu A, Wang R, Zhang S, Qi M, Zhao W, Shi Y, Wang J, Wei J, Zhang L, Xiao L. 2016. Common occurrence of Cryptosporidium hominis in horses and donkeys. Infection, Genetics and Evolution, 43, 261-266.

15. Khan A, Shaik JS, Grigg ME. 2018. Genomics and molecular epidemiology of Cryptosporidium species. Acta Tropica, 184, 1-14.

16. Laatamna AE, Wagnerová $\mathrm{P}$, Sak B, Květoňová $\mathrm{D}$, Xiao L, Rost M, McEvoy J, Saadi AR, Aissi M, Kváč M. 2015. Microsporidia and Cryptosporidium in horses and donkeys in Algeria: detection of a novel Cryptosporidium hominis subtype family (Ik) in a horse. Veterinary Parasitology, 208, 135-142.

17. Li F, Su J, Chahan B, Guo Q, Wang T, Yu Z, Guo Y, Li N, Feng Y, Xiao L. 2019. Different distribution of Cryptosporidium species between horses and donkeys. Infection, Genetics and Evolution, 75, 103954.

18. Qi M, Zhou H, Wang H, Wang R, Xiao L, Arrowood MJ, Li J, Zhang L. 2015. Molecular identification of Cryptosporidium spp. and Giardia duodenalis in grazing horses from Xinjiang, China. Veterinary Parasitology, 209, 169-172.

19. Ryan U, Zahedi A, Paparini A. 2016. Cryptosporidium in humans and animals-a one health approach to prophylaxis. Parasite Immunology, 38(9), 535-547.

20. Wagnerová P, Sak B, McEvoy J, Rost M, Matysiak AP, Ježková J, Kváč M. 2015. Genetic diversity of Cryptosporidium spp. including novel identification of the Cryptosporidium muris and Cryptosporidium tyzzeri in horses in the Czech Republic and Poland. Parasitology Research, 114, 1619-1624.

21. Xiao L, Escalante L, Yang C, Sulaiman I, Escalante AA, Montali RJ, Fayer R, Lal AA. 1999. Phylogenetic analysis of Cryptosporidium parasites based on the small-subunit rRNA gene locus. Applied \& Environmental Microbiology, 65, 1578-1583.

Cite this article as: Wang W, Zhang Z, Zhang Y, Zhao A, Jing B, Zhang L, Liu P, Qi M \& Zhao W. 2020. Prevalence and genotypic identification of Cryptosporidium in free-ranging and farm-raised donkeys (Equus asinus asinus) in Xinjiang, China. Parasite $27,45$. 
An international open-access, peer-reviewed, online journal publishing high quality papers on all aspects of human and animal parasitology

Reviews, articles and short notes may be submitted. Fields include, but are not limited to: general, medical and veterinary parasitology; morphology, including ultrastructure; parasite systematics, including entomology, acarology, helminthology and protistology, and molecular analyses; molecular biology and biochemistry; immunology of parasitic diseases; host-parasite relationships; ecology and life history of parasites; epidemiology; therapeutics; new diagnostic tools.

All papers in Parasite are published in English. Manuscripts should have a broad interest and must not have been published or submitted elsewhere. No limit is imposed on the length of manuscripts.

Parasite (open-access) continues Parasite (print and online editions, 1994-2012) and Annales de Parasitologie Humaine et Comparée (1923-1993) and is the official journal of the Société Française de Parasitologie. 